\title{
The Amaury Talbot Fund Annual Prize, 1971
}

The Amaury Talbot Prize for 1971 has been awarded to Dr. Jack Goody for Technology, Tradition and the State in West Africa, published by the International African Institute in February $197 \mathrm{I}$. The prize is awarded annually for the most valuable work of anthropological research published during the year, preference being given to Nigeria and West Africa. The theme of Dr. Goody's book is that certain aspects of traditional African social systems, and hence also of contemporary African life, have been misunderstood because of a failure to appreciate what is implied by important differences between the technologies of the major traditional states in Africa, on the one hand, and those of the European and Asian continents, on the other. He also shows that the reconstruction and interpretation of traditional political systems calls for a combination of historical and comparative sociological approaches.

\section{University of Khartoum: Institute of African and Asian Studies}

THE University of Khartoum is establishing an Institute of African and Asian Studies to encourage, promote, co-ordinate and communicate research studies and teaching on the Sudan, and also more generally on Africa and Asia in the fields of humanities, social sciences, and related subjects. It will also provide postgraduate courses leading to an M.A. and a Diploma in Afro-Asian Studies and establish a documentation centre in the fields of its specialization. As an inter-disciplinary Institute it will incorporate the Sudan Research Unit (see Africa, xxxix. 3, 1969, p. 300) and function in close co-operation with the faculties of arts, law, and economic and social studies where Afro-Asian courses pertaining to AfroAsian studies are offered. The Sudan Research Unit's Bulletin of Sudanese Studies will continue to be published, in addition to occasional papers on Sudanese and African themes. It is hoped that the Institute will start in July $197^{2}$. Further information may be obtained from the Academic Secretary, University of Khartoum, P.O. Box $32 x$, Khartoum, Sudan.

\section{Research in the Western Indian Ocean Area}

Professor Irvine Richardson has recently spent a year's sabbatical leave in Madagascar and Mauritius. The Malagasy Republic, Mauritius and dependencies, Reunion, Seychelles, and the Comorian Islands are linked in several ways to Africa and also to other localities in and around the Indian Ocean. Unfortunately researchers in this region are still somewhat isolated from each other and spend considerable time trying to contact scholars with kindred pursuits and sources of useful information. In an attempt to improve this situation Professor Richardson has volunteered to act as a 'clearing house'. He would be glad to hear from those who have worked on any kind of research project in these areas or who are planning to do so. Please note that this appeal for information is not limited to the social sciences and humanities. Appropriate news items and bibliographia will be especially welcome. Write to Dr. Irvine Richardson, African Studies Center, Michigan State University, East Lansing, Michigan 48823.

\section{Makerere University, Kampala: Programme in Agricultural Economics}

IN July 1972 the Department of Rural Economy at Makerere University is starting a new Regional Programme for the M.Sc. degree in Agricultural Economics, sponsored by the Ford Foundation. The need for rapid development of the agricultural sector in East and Central Africa is emphasized in all the Development Plans of the six countries since agriculture contributes so largely to the national economies and economic growth is to a very considerable extent conditional on the modernization of this sector.

The programme will be open to students, who fulfil the entrance requirements, from Uganda, Ethiopia, Kenya, Tanzania, Zambia, and Malawi, who will normally be nominated 
by the appropriate government department or by the respective national universities. Students from other African countries may also be admitted to the programme. It is planned that students will do their course work at Makerere, go back to their own countries for field research, and return to Makerere for writing up.

\section{History of the Kingdom of Warri, Nigeria}

Mr. J. O. E. SAGAY of Warri is to visit Bahia, Rio de Janeiro, Lisbon, and Rome (where there are missionary archives) to gather material for a detailed history of the Warri kingdom. His research will be assisted by the Warri Land Trust which is responsible for supervising Itsekiri land under the Chairmanship of Professor Origse Thomas of the Lagos University Teaching Hospital.

\section{R. E. Bradbury Memorial Appeal}

THE appeal for a prize fund in memory of the late Dr. R. E. Bradbury, which was launched a year ago, has produced contributions totalling $£^{6} 7^{2} \cdot 99$. The appeal committee, consisting of Professor J. D. Fage, Professor Daryll Forde, Dr. P. C. Lloyd, Professor A. F. C. Ryder, and Professor M. G. Smith, has divided this sum into three equal parts which have been presented to the three institutions with which Dr. Bradbury served during his career as a social anthropologist-University College, London, the University of Ibadan, and the University of Birmingham. This will enable each of them to establish a R. E. Bradbury Memorial Prize to be presented annually for outstanding work by their students in the fields to which Dr. Bradbury had himself so notably contributed.

\section{Grants-in-Aid for Preparation of Oral Data Collections}

IN order to encourage the scholarly presentation of oral data collections for deposit, the African Studies Association (U.S.A.) has, through the generosity of the Ford Foundation, been able to give a limited number of grants-in-aid to assist with the necessary costs in time, informants, and materials. Further information may be obtained from the African Studies Association, 2 I 8 Shiffman Center, Brandeis University, Waltham, Mass. o2 I 54.

\section{Index to African Periodical Literature}

Compiled by the Library of Congress African Section, Africa South of the Sahara: Index to Periodical Literature $1900-1970$ is a four-volume work, published in 1971 by G. K. Hall \& Co., Boston, Mass., at $\$ 260$ the set. Most references pertain to articles published during the last ten years in the major scholarly journals of Africa, Asia, Europe, and North America. The arrangement of the Index is by area and by subject within areas. The subjects covered include the humanities, social sciences, African literature, law, natural sciences, etc.

'African Archives'

African Archives is a series of files on the history of Africa. Each file portrays a particular period or subject and contains a selection of documents drawn from historical recordsmaps, drawings, tables, photographs, and narrative text. The format, which was devised in Zambia, enables readers to build up their own archives system by adding notes, photographs, and press cuttings to individual files. Each file is complete in itself. They will be of special interest to senior school and university students. File I, entitled 'Safari' contains a selection of documents on East Africa's history, with particular emphasis on the nineteenth century.

The series is published by Oxford University Press, P.O. Box 2335, Lusaka, and the National Education Company of Zambia (NECZAM), P.O. Box 2664, Lusaka. 